\title{
When Learning English is Compulsory at School: Fluctuations in L2 Motivational Self System
}

\author{
Maryam Azarnoosh \\ Department of English, College of Humanities, Semnan Branch, Islamic Azad University, Semnan, Iran \\ E-mail: azarnoosh.86@gmail.com; m.azarnoosh@semnaniau.ac.ir
}

Received: 17-05-2014

Accepted: 07-07-2014

Published: 01-11-2014

doi:10.7575/aiac.ijalel.v.3n.6p.102

URL: http://dx.doi.org/10.7575/aiac.ijalel.v.3n.6p.102

\begin{abstract}
Research findings highlight the role of motivation in the long-term process of learning a second/foreign language. One's motivation can change even in a short period of time under the influence of multifarious factors. To enrich our understanding of the attitudinal/motivational basis of foreign language learning this study attempts to investigate L2 motivational fluctuation, and the possibility of predicting EFL learners' motivated learning behavior in light of Dörnyei's $(2005,2009)$ theory of L2 motivational self system. To this end, 1670 junior high and high school students studying English as a compulsory subject in Iran filled out L2 motivational self system questionnaire. Independent samples t-test and regression analyses were applied; and the findings indicated a higher motivational disposition for junior high school students in comparison to high school students, except for their attitudes towards L2 community. For both groups, attitudes towards L2 learning was the best predictor of students motivated learning behavior.
\end{abstract}

Keywords: L2 Motivational Self System, Motivation, Ideal L2 Self, Ought-L2 Self, Attitudes towards L2 learning, Iran

\section{Introduction}

Motivation, a multifaceted construct and one of the most important considerations in language learning, has received special attention incomparable to any other individual difference factor in the field of second language learning (Ellis, 2008). Many topics such as the role of integrativeness (Gardner, 1985, 2001), self-determination theory (Noels, 2001), or attribution theory (Ushioda, 2001), the process model of motivation (Dörnyei \& Ottó, 1998) and the second language motivation of a given group of learners such as Hungarians (e.g., Dörnyei et al., 2006) are some of the motivational research spotlights. However, there have been shifts of focus highlighting promising new conceptual themes and marking a significant milestone in the evolution of new motivational theories such as the L2 motivational self system (Dörnyei, 2005, 2009). Moreover, researchers have put it into practice in different linguistic and cultural contexts (e.g., Al-Shehri, 2009; Csizér and Kormos, 2009; Papi, 2010; Ryan, 2009; Taguchi et al., 2009; Yang \& Kim, 2011).

Contrary to the widely accepted issue that one's motivation can change during the language learning process (Dörnyei, 2005), not much is known about the L2 selves stability and actual development over time (Dörnyei \& Ushioda, 2009b; Waninge, 2010). In a foreign language context like Iran where learning English is compulsory at school and students experience little contact with native speakers and their culture, exploring language learning motivation of school students may shed light on the aforementioned issue and add to the body of motivational research in Iran. Thus, this study intends to picture the differences in school students' L2 motivational self system when they study English as a compulsory subject in an Asian context. Moreover, it investigates the possibility of predicting EFL learners' motivated learning behavior from the motivational factors.

\section{Review of Literature}

\subsection{The L2 Motivational Self System}

L2 motivational self system, is a major reformation of previous motivational thinking with roots firmly set in L2 motivation research (Noels, 2003; Ushioda, 2001), and significant theoretical developments in psychology, that is, possible selves (Markus, \& Nurius, 1986) and discrepancy theory (Higgins, 1987). This new conceptualization of L2 motivation developed based on the findings of the large scale research on motivation in Hungary (Dörnyei \& Csizér, 2002; Dörnyei et al., 2006; Csizér \& Dörnyei, 2005) and the issues raised with regard to the application of integrativeness to contexts different from those studied by Gardner, and a whole-person perspective towards motivation (Dörnyei, 2005, 2009).

The L2 motivational self system has three main dimensions: the ideal L2 self, ought-to L2 self, and English learning experience. The ideal L2 self is "the representation of the attributes that someone would ideally like to possess" (Dörnyei, 2010, p.257), in other words, it is the ideal image of the L2 user one wishes to be in the future. The vision of being a fluent L2 user interacting with foreigners is an example of a powerful motivator which helps to reduce the discrepancy between the person's actual self and ideal image. This dimension of L2 motivational self system significantly correlates with integrativeness and explains more variance in learners' intended effort (e.g., Kormos \& 
Csizér, 2008; Ryan, 2009; Taguchi et al., 2009). In fact, these variables share the same underlying construct domain (Dörnyei, 2010). Moreover, learners' visual style preference and overall visual/imaginative capacity significantly correlate with their ideal language selves (Al-Shehri, 2009;Yang \& Kim, 2011). Language learners' global concerns, that is, their engagement in global issues, also have major bearings on their ideal L2 selves. In other words, learners' higher level of international posture and frequency of communication lead to a more strongly sustained vision of ideal selves (Yashima, 2009).

The ought-to L2 self refers to "the attributes that one believes one ought to possess" (Dörnyei, 2005, p.105). This less internalized and more extrinsic aspect of the L2 self, which corresponds to Higgins' (1987) ought self and the extrinsic constituents in Noels (2003) and Ushioda's (2001) taxonomies (see Dörnyei, 2005, 2009), includes attributes such as various duties, obligations, or expectations one ought to fulfill to avoid possible negative outcomes. For instance, in the case of learning an L2 to fulfill one's family or teacher's expectations, the ought-to L2 self can act as the major motivator. In three countries, Japan, China, and Iran, family influence and the prevention-focused aspects of instrumentality were found to have influences on this variable, but the effect on learners motivated behavior was far less than that of the ideal L2 self (Taguchi et al., 2009). Also in Hungary, a similar relationship between parental encouragement and ought-to L2 self was found (Csizér \& Kormos, 2009). According to findings in self psychology (e.g., Oyserman \& Markus, 1990), a learner's ideal self should be in balance with such a prevention-focused future selfguide to function optimally.

The third aspect of L2 motivational self system, the L2 learning experience "concerns situation-specific motives related to the immediate learning environment and experience" (Dörnyei, 2005, p.106). This dimension which has links with the actional phase of Dörnyei's process oriented model (Dörnyei \& Ottó, 1998) is also related to Noels' (2003) and Ushioda's (2001) intrinsic categories (see Dörnyei, 2005, 2009). In the studies of Csizér and Kormos (2009) and Taguchi et al. (2009), this dimension illustrated the strongest influence on motivated behavior. A 'situated' approach and contextual factors, such as, pedagogy, classroom environment, task design, cultural setting curriculum, teacher, peer group, and teaching materials, play a crucial part in motivating students. This is because some language learners' initial motivation to learn is not drawn from their "internally or externally generated self images but rather from successful engagement with the actual language learning process" (Dörnyei, 2009, p. 29).

\subsection{Fluctuation in Motivation and Compulsory Language Learning}

In the long process of learning a foreign/second language, an individual's motivation is never stable but fluctuates (e.g., Dörnyei, 2000, 2001; Ushioda, 2001; Williams \& Burden, 1997). In fact, motivational processes happen in real time, so Dörnyei and Ottó (1998) asserted the necessity of developing a construct accounting for changes in motivation that includes a temporal dimension. A number of other studies also acknowledge the changing nature of L2 motivation (e.g., Shedivy, 2004; Shoaib\&Dörnyei, 2005). In Shoaib and Dörnyei's study, significant "recurring temporal patterns and motivational transformation episodes" (Dörnyei, 2005, p.88, original italics) were identified over a period of approximately two decades in the lives of the learners. This accords with research findings implying that developments in language learning motivation are not always observed as increasing loss or growth "since patterns of change and stability are felt by learners to evolve differently for different aspects of L2 motivation" (Ushioda, 1996, p.239).

In some studies, the fluctuation in learners' motivation has been studied where learning one or more foreign languages is compulsory. The compulsory nature of language learning, as a demotiving factor (Dörnyei \& Ushioda, 2011), leads to motivational variations which have been studied in relation to a factor such as age. Such studies indicate that motivation decreases with age, for instance, Williams, Burden and Lanvers (2002) found that although British foreign language learners had shown initial language learning eagerness, their motivation declined towards the end of the compulsory program. Similar findings were reported in other countries such as Canada (MacIntyre et al., 2002), Sweden (Henry, 2009), Hungary (Dörnyei et al., 2006), Japan (Koizumi \& Matsuo, 1993, cited in Dörnyei, 2005) and Indonesia (Lamb, 2007).

Considering compulsory language learning contexts, some studies have reported students' preference and types of motivation. For instance, instrumental motivation was more favored than integrativeness by Libyan (Al Moghani, 2003) and UAE students (Qashoa, 2006). Likewise, in Sweden, girls had instrumental motivation in learning the foreign language, while boys studied English just because it was compulsory (Öhlund, 2007). In Hungary, ideal L2 self was found to be an antecedent of students' motivated behavior (e.g., Csizér \& Lukács, 2010; Csizér \& Kormos, 2009; Kormos \& Csizér, 2008) and significantly related to attitudes to the learning situation (Kormos \& Csizér , 2008) which was also observed in Sweden (Henry, 2007). In Japan, students' ideal L2 self had a more direct relationship with their motivated behavior than integrativeness had (Ryan, 2009). In Iran, although ideal L2 self of secondary students did not seem to be related to their actual motivated behavior (Papi \& Abdollahzadeh, 2012), it was a predictor of students' intended effort (Azarnoosh \& Birjandi, 2012; Papi \&Teimouri, 2012). In addition, ought-to L2 self, being socially constructed, had a weak correlation in shaping Hungarian students' learning behavior (Csizér \& Kormos, 2009). In Iran, secondary and high school students were not significantly different from each other in terms of ought-to L2 self (Papi \&Teimouri, 2012), but secondary school boys displayed a higher level of it (Azarnoosh \& Birjandi, 2012).

Concerning L2 motivational self system, Dörnyei and Ushioda (2009b) believe that the temporal development of the future self-guides is an unexplored area; although self-images that are developed over a period of time are quite robust, the stability and fluctuation of ideal and ought-to selves has to be investigated to represent a clear picture of how they take form and develop. Thus, with the scarcity of empirical results, "examining the temporal progression of L2 
motivation is a potentially fruitful research direction that can significantly enrich our understanding of the attitudinal/motivational basis of language learning" (Dörnyei, 2005, p.88).

\subsection{English Language Learning in Iran}

Generally, teaching English in Iran seems to be based on future needs of students to read, and sometimes to translate English books, and journals (Eslami \& Fatahi, 2008). Nevertheless, what gives impetus to students to learn English varies from passing their English exam at school to entering prestigious universities, proceeding to the highest social and education levels, studying and living abroad, and accessing the latest information. Considering these factors and youth extended interests in the growing technology, science and international communication which are far beyond reading and translation, learning English is taken to be much more important than ever before.

In Iran, school students previously had to study English for seven years. It started from the first grade of junior high school up to the last year of high school including the pre-university level. However, different factors such as the textbooks, the applied methodology, the evaluation system, the rarity of being exposed to the language outside classes (Rahimi, Riazi, \& Saif, 2008) and lack of motivation (Moiinvaziri, 2007), led to an outcome far from satisfactory. It is believed that most students neither achieved full competence in using the English language nor could interact with confidence (Dahmardeh, 2009). However, according to Kheirabadi and Alavi Moghaddam (2014), a turning point in teaching English in Iran follows the recent reform in the education system. Since 2013, students have to study English for six years from grade seven to 12 in the six years of junior and senior high school during which they study newly designed English textbooks with the main aim of learning the four skills through communicative approaches.

\subsection{Research on Motivation in Iran}

Research on L2 motivation in the world has strongly been influenced by Gardner's motivation theory with integrativeness as its main construct. In many studies, this construct turned to a key factor in predicting motivated behavior and success in language learning (e.g., Clément, Dörnyei, \& Noels, 1994; Dörnyei, 1990), and became central in most models of L2 motivation (e.g., Dörnyei, 1994, MacIntyre, Clément, Dörnyei, \& Noels, 1998). Similarly, in the context of Iran, a large number of studies on English language motivation primarily focused on Gardner's motivational theory (e.g., Chalak \& Kassaian, 2010; Dastgheib, 1996; Vaezi, 2008), and so far only a few studies have taken the new framework of L2 motivational self system into consideration. Such studies have tried to investigate aspects like validity of the framework, relationship between L2 motivational components, possibility of replacing integrativenss with ideal L2 self, changes in learners' motivation, and motivational differences based on gender, age and educational level. Some of these studies which were conducted at school level (e.g., Azarnoosh \& Birjandi, 2012; Kiany, Mahdavy, \& Ghafar Samar, 2012; Papi, 2010), or both school and university levels (e.g., Papi \& Teimouri, 2012; Taguchi et al., 2009) in Iran are reviewed below.

In Kiany et al.'s (2012) study, 401 high school students filled out a questionnaire to reveal the L2 motivational changes and the impact of the educational system on their motivation. Based on descriptive analysis, all motivational factors systematically declined except for L2 anxiety which increased as the students approached the last high school years. Significant declines were also observed in the last years' rate of instrumental-promotion, interest, and ideal L2 self. While the decrease in ought-to L2 self and instrumental-prevention was small and statistically insignificant, the level of L2 anxiety increased which was also insignificant. The researchers concluded that the "context is more in favor of extrinsic motivational forces rather than the intrinsic types" and "the curriculum has little effect on students' attitudes towards L2 community and cultural interest” (p. 12) since there was almost no change in students' cultural orientations.

In another study conducted by Papi (2010), a questionnaire was used to investigate the relationship between the three main components of the L2 motivational self system, English anxiety and intended effort among 1011 high school students. All the factors in the structural model were found to be significant contributors to learners' intended effort and motivating students to varying degrees in their attempt to study English. Students' English anxiety decreased in accordance with their ideal L2 self and L2 learning experience, whereas ought-to L2 self was the factor that significantly made them more anxious. Consequently, it was indicated that students' motivational regulations and approach/avoidance tendencies and their anxiety had strong associations providing a clear picture of students' emotional state.

Azarnoosh and Birjandi (2012) also conducted a study with 1462 participants to compare secondary school students' motivational status according to their gender. Although all learners displayed the same positive attitude to learning English, girls displayed a higher level of ideal L2 self and boys had a higher level of ought-to L2 self. For both groups, English learning attitudes among the three constituents of L2 motivational self system and students' intended effort had the strongest association. In addition, the best predictor of students' intended effort was attitudes to learning English. They concluded that among other factors the immediate learning environment is of particular importance in shaping learners' attitudes; moreover, students' language learning motivation can be affected by their parents' gender-based stereotypes.

In another comparative study (Taguchi et al. 2009) conducted in China, Japan, and Iran, the participants from Iran were 1309 middle school students and 719 university students. The data gathered from administering a questionnaire determined the relationship between the ideal L2 self and integrativeness and the possibility of relabeling integrativeness as ideal L2 self. Two separate aspects of instrumentality - promotion and prevention - were identified which were respectively highly correlated with participants' ideal and ought-to L2 selves. Unexpectedly, 
instrumentality-promotion and ought-to L2 self were significantly associated in the Chinese and Iranian samples. Moreover, the validity of the L2 motivational self system was supported by SEM analyses for all three samples.

Additionally, age-related motivational differences among 1041 school and university students were investigated by Papi and Teimouri (2012). The motivational factors which improved with age up to university level were ideal L2 self, L2 learning experience, instrumentality-promotion, attitudes towards L2 culture and community (i.e., promotion-focus variables). However, ought-to L2 self, family influence and instrumentality-prevention (i.e., preventional-focus variables) declined with age. Moreover, only variables with a promotional orientation were the predictors of all students' motivated learning behavior among which English learning experience and the ideal L2 self were the strong ones. Students also became more motivated to learn English as they entered high school, and this group of learners were found to be the best motivated group as their motivated behavior and ideal L2 self was high and they ranked first specifically in attitudes towards language learning and L2 community and culture. In contrast, preventional-focus variables were stronger among the younger learners.

All the above-mentioned studies have focused on L2 motivational self system of various cohorts of participants from different perspectives. However, none of them have specifically investigated motivation of school students who only experience learning English at schools as a compulsory subject. For a large number of students, schools are the only place where they encounter English. Therefore, to improve these students' language learning motivation, investigating their level of motivation and identifying sources of their motivated learning behavior seems necessary. Thus, the following research questions were formulated:

1. Is there any significant differences between junior high and high school students' motivation in terms of their L2 motivational self system?

2. Can motivational factors predict EFL learners' motivated learning behavior?

\section{Method}

\subsection{Participants}

In this study, the participants were selected based on quota sampling method (Dörnyei, 2007). The sampling frame consisted of junior high and high school students; and the main proportions of the subgroups defined by parameters were gender, school year (based on the previous education system), and residential status. Accordingly, the quotas were met by selecting and approaching those participants the researcher had access to. A total of 2964 Iranian school students participated in the study; however, this study reports the findings for the 1670 students who only studied English as a compulsory school subject and stated not to have ever participated in any other English classes except for their usual school classes. These participants were 843 junior high school students, 386 females and 457 males, with the age range of 12 to 16 and the mean age of 13.89; and 827 high school students, 404 females and 423 males, ranging in age from 14 to 19 with the mean age of 16.43. Since pre-university (4th-grade high school) students were getting prepared to sit for the public university entrance examination, they were not included in the study. In addition, to minimize any school bias the sample was selected from schools from all over Semnan province. Participants were selected from cities, towns, and rural areas of the province, 1291 urban students (653 junior high and 638 and high school students) from five cities and 379 rural students (190 junior high and 189 high school students) from five remote areas.

\subsection{Instrument}

For data collection, the Persian version of Taguchi et al. (2009) questionnaire was used. It was piloted with 244 students, at both levels, filling out the questionnaire and some joining follow up interviews to insure the comprehensibility of the items. The questionnaire contained two parts: the first part measured learners' attitudes and motivation towards learning English and the second part consisted of questions about learners' background. The questionnaire consisted of 10 factors measured by a six-point Likert scale with acceptable reliability coefficient for both groups (see Appendix).

\subsection{Procedure}

Before data collection, several official letters were issued by the Educational Organization of Semnan province, each city, and district. Then the researcher personally approached the schools and provided information about the survey and details of administration for the school principals and, following their permission, for the teachers. With the cooperation of teachers and after a brief explanation about the study, the subjects filled out the questionnaires during their regular class time which took almost 15 minutes on average to be completed.

\section{Results and Discussion}

Data analysis commenced with submitting the data to SPSS 16. A descriptive analysis was conducted to provide basic information on junior high and high school students. Then an independent samples $t$-test was run to investigate the differences between the motivational/attitudinal factors of the two levels. This was followed by regression analyses to identify statistically significant predictors of learners' motivated learning behavior.

In order to answer the first research question and determine the differences between junior high and high school students on the motivational/attitudinal factors, an independent samples $t$-test was run. Since the probability associated with the Levene $\mathrm{F}$ for each factor was higher than the significance level of .05 , in all cases, the two groups enjoyed homogenous variances. The results of the $t$-test (Table 1) revealed that there was a significant difference between the mean scores of the two groups on all the factors except attitude towards L2 community $(t=1.77, p>.05)$. That is to say, motivational dispositions of junior high school students compared to high school students stand at a higher level. 
The descriptive statistics in Table 1 shows that the two types of instrumentality have the highest mean values for both groups. In addition, junior high school students' mean scores on ideal L2 self and integrativeness were high (above 4) and almost the same which indicates the closeness of the two constructs. Since no scales had mean values lower than three, it can be concluded that students of both groups hold positive attitudinal and motivational dispositions.

Despite the significant differences found for both groups, the effect size (Cohen, 1988) of the scales indicated that the findings were meaningful but to a different extent. The effect size values of integrativeness, cultural interest, and instrumentality-prevention were weak (below .01); the constituents of L2 motivational self system, criterion measures, and instrumentality-promotion displayed a weak to moderate value (below .06); and the only moderate value belonged to family influence.

Table 1. Results of independent samples $t$-test

\begin{tabular}{lllllll}
\hline Scales & Level & Mean & SD & t & df & Effect size $^{\mathrm{a}}$ \\
Ideal L2 self & JHS & 4.18 & 1.21 & 8.21 & 1615 & .04 \\
Ought-to L2 self & HS & 3.68 & 1.2 & & & \\
& JHS & 3.66 & 1.05 & 6.50 & 1613 & .02 \\
Criterion measures & HS & 3.31 & 1.07 & & & \\
Instrumentality- promotion & JHS & 4.08 & 1.17 & 5.74 & 1627 & .02 \\
& HS & 3.74 & 1.24 & & & \\
Instrumentality-prevention & JHS & 4.44 & 1.00 & 5.44 & 1627 & .04 \\
& JHS & 4.17 & 0.10 & & & \\
Family influence & HS & 4.41 & 0.93 & 4.47 & 1591 & .01 \\
& JHS & 3.71 & 0.99 & 10.26 & 1611 & .06 \\
Attitudes to learning English & JHS & 3.20 & 1.02 & & & \\
& HS & 3.88 & 1.29 & 6.45 & 1601 & .02 \\
Attitudes to L2 community & JHS & 3.48 & 1.24 & & & \\
& HS & 3.73 & 1.35 & 1.77 & 1614 & -- \\
Cultural interest & JHS & 3.42 & 1.34 & 3.08 & 1629 & .006 \\
Integrativeness & HS & 3.21 & 1.37 & & & \\
& JHS & 4.13 & 1.37 & 2.2 & 1624 & .003 \\
\hline${ }^{a}$ Eta Squared, JHS = Junior High School, HS $=$ High School & &
\end{tabular}

To answer the second research question and specify the factors that act as predictors of students' criterion measures (i.e., motivated learning behavior), multiple regression analyses with a stepwise approach was employed. As Table 2 displays, out of the 10 factors examined, attitudes to learning English which is assumed to belong to the component of L2 learning experience in Dörnyei's (2005) model was the best predictor for both groups but to a greater extent for junior high school students. The other two constituents of L2 motivational self system, ought-to L2 self and ideal L2 self, were the next predictors for the high school group, respectively, while ought-to L2 self was not present in the regression model for junior high school group. Integrativeness was also a motivational predictor for both groups with rather the same strength as ideal L2 self. Similar to attitudes towards learning English, instrumentality-promotion was more motivating for junior high school students than for high school students. Finally, sharing a predictive value close to that of instrumentality-promotion and integrativeness, attitudes towards L2 community negatively influenced high school students' motivated behavior.

Table 2. The final models of regression analyses predicting the criterion measures

\begin{tabular}{lllllll}
\hline Groups & Predictors & $\mathrm{R}^{2}$ & $\mathrm{~F}$ & $\mathrm{~B}$ & $\mathrm{SEM}$ & $\mathrm{Beta}(ß)$ \\
& & .71 & $9.31^{* *}$ & & & \\
& & & .44 & .03 & .50 \\
& Attitudes to learning English & & & .25 & .04 & .21 \\
& Instrumentality-promotion & & & .16 & .03 & .16 \\
& Ideal L2 Self & & & .09 & .03 & .10 \\
\hline High School & Integrativeness & .68 & $20.05^{* *}$ & & & \\
& Attitudes to learning English & & & .40 & .03 & .41 \\
& Instrumentality-promotion & & .15 & .04 & .12 \\
& Ideal L2 Self & & & .18 & .04 & .18 \\
& Integrativeness & & & .16 & .04 & .17 \\
& Ought-to L2 Self & & .27 & .03 & .23 \\
& Attitudes to L2 community & & -.14 & .03 & -.15 \\
\hline
\end{tabular}


As the results of the $t$-test indicate, school students' foreign language motivation declines with age which confirms the findings in various linguistic contexts including Canada (MacIntyre et al., 2002), Indonesia (Lamb, 2007), Sweden (Henry, 2009) and Hungary (Kormos \& Csizér, 2008) where foreign language learning is compulsory. These contexts share common features, such as, the compulsory nature of language learning which leads to boredom, students' gradual recognition of the effort required to learn a foreign language (e.g., Henry, 2009; Williams et al., 2002), and the general prevalent dissatisfaction of students of this age with school (Azarnoosh, 2011; Henry, 2009) can be possible explanations of the results. In the case of Iran, some other issues, such as, the traditional educational principles adhered to, the applied methodology, and the evaluation system as the constituents of the immediate learning context also influence and decrease students' intended effort and willingness to learn a foreign language (Azarnoosh, 2011; Papi, 2010; Papi \& Abdollahzadeh, 2012; Papi \& Teimouri, 2012).

The results are also interpretable in the socio-educational context of Iran. Due to Iranian culture, families are much respected in a way that their demands and expectations take precedence over personal will and desire of children. As Brophy (2009) expresses the encouragement and pressure from culture at large, peers and significant others within one's social circle partly lead to the growth and change of one's identity and motivational dispositions. In the case of younger learners, more support and encouragement is provided by families (Elliot et al., 2005) which in turn, positively affects their language learning attitudes. Considering high school students, their age-related lower level motivational dispositions (Table 1) seem justifiable in light of the changes that take place in adolescent years. Changes in both social relations and instructional practices may negatively influence high school students' motivation. They include changes in family and peer relations, as well as, social and educational changes due to growing older and transition from junior high school to high school level. Parents' involvement in students' school affairs usually declines during this period (Wigfield \& Wagner, 2005), and the amount and difficulty level of English materials they have to study at high school radically increases. The high school teaching/learning situation depicted in many studies (e.g., Kiany et al., 2012; Papi \& Abdollahzadeh, 2012) leads to a decline in students' motivational perspectives as they reach the last years of high school (Kiany et al., 2012). Moreover, high school students' change of perspective to a more realistic one about the need to know and apply English in their future life (Azarnoosh, 2011) can result in their lower level of motivation and willingness to invest effort in language learning.

Although in this study motivational/attitudinal factors were found to decline with age, Papi and Teimouri (2012) came to a different conclusion. In their study, for secondary and high school students, all motivational aspects either increased with age or had a similar level except for instrumentality-prevention which decreased with age. This perceptible difference may have originated from $54 \%$ of high school participants' extra language learning experience due to attending private language schools in addition to their regular school classes. Nevertheless, in the present study, the participants, whether living in an urban or rural area, had only learned English at school as a compulsory subject and had never benefited from attending extracurricular classes and experiencing a different language learning environment.

The result of the regression analyses, similar to the findings of studies conducted in different compulsory language learning contexts (e.g., Csizér \& Kormos, 2009; Ghenghesh, 2010; Henry, 2009; Kormos \& Csizér, 2008), denotes the importance of immediate learning environment in shaping learners' attitudes (Dörnyei, 2009). Moreover, as Nikolov (1999) stated younger learners were found to be more influenced by their language learning experiences. Classroom factors (e.g., the learning context, teacher, materials, activities, etc.) are believed to have a leading impact on students' attitude and learning experiences that affect the extent to which learners are ready to invest in language learning (Csizér \& Kormos, 2009). However, the findings in this regard are in contrast with Papi and Teimouri's (2012) findings in that high school students displayed significantly more positive attitudes than junior high school students did. This again can be due to students' higher participation percentage in private language centers and the greater impact of such classes on improving students' learning attitudes due to their relatively different teaching/learning conditions.

Ideal L2 self and integrativeness were also other predictors of both groups' motivated language learning. This result, similar to the findings of others (e.g., Kormos \& Csizér, 2008; Taguchi et al., 2009), indicates that ideal L2 self and integrativeness with a high correlation tap into the same construct (Dörnyei, 2010). Additionally, the replacement of integrativeness with the ideal L2 self is justifiable as this scale has a better predictive power toward learners' motivated learning behavior than integrativeness does for both groups of learners.

Instrumentality-promotion was also more motivating for junior high school students than for high school students. The pragmatic benefits of learning English seem to have a greater impact on the junior high school students' motivated behavior. This change of perception seems to be age-related and resulting from students' dissatisfaction with the way English is taught at high schools, their expectations about foreign language learning that are not met by classroombased learning (Henry, 2009) and the clearer picture they gain about the future of learning English and its' benefits they would later enjoy as an average Iranian adult living in the country (Azarnoosh, 2011).

As adolescence is a period in which crucial decisions affecting one's life should be made, such as, decisions about one's education and possible occupation (Papi \& Teimouri, 2012; Wigfield \& Wagner, 2005), observing ought-to L2 self among the motivational predictors for the high school group supports Taguchi et al.'s (2009) idea in that many Iranian parents place much hope onto their children's future because of their own unfulfilled dreams. Having much influence on children's choice of major and career, parents, in return, expect their children's success and the honor and prestige it brings to them. Therefore, studying English can be considered a prerequisite to students' prosperity in higher education, finding a prestigious job and even marrying, specifically for high school students with proximal future dreams. 
Among the predictors, only attitudes towards L2 community negatively influenced high school students' motivated behavior. The results in this respect suggest that lack of contact with speakers of the language, and the political, cultural and religious situation of the country, as well as, the policy families pursue towards learning English (Haddad Narafshan \& Yamini, 2011) might be decisive factors affecting students' attitudes about L2 community and in turn their motivation. The biased and simplistic cultural presentations of textbooks (Aliakbari 2004) are not helpful in developing intercultural competence and cultural understanding in high school students. Yet, they reinforce pre-existing assumptions and stereotypes about L2 community. This situation does not promote motivated learning behavior of learners let alone the long-term benefits attributed to teaching culture such as a better understanding of one's own identity, cross-cultural understanding, and achievement of academic professionals and social and personal goals (CelceMurcia, 2001) which specifically pertain to high school students' future needs and expectations.

Although junior high school textbooks are different from high school textbooks in terms of difficulty, type and amount of information, they are similar in neglecting cultural issues (Dahmardeh, 2009). In contrast to studies which indicate that attitudes to/interest in L2 community and culture increase by age (e.g., Kormos \& Csizér, 2008; Papi \& Teimouri, 2012), in the present study, high school students' motivation was negatively affected by attitudes to L2 community. It seems that older students feel the need to establish international contacts, to know more about the global culture (Arnett, 2002), and to be identified with some kind of cosmopolitan identity or international posture (Yashima, 2009) as an indispensable part of the globalization process (Lamb, 2007). This will not be possible without knowing a global language like English; however, at times confusion may reign due to the conflicts between students' local and global identities which may result in "a temporary loss of interest in learning English" (Lamb, 2007, p.16). In the case of high school students whose language learning is confined to studying the aforementioned textbooks at school, the global desires might remain unfulfilled and may negatively affect students' motivational propensities.

\section{Conclusion}

This study examined the variations in the main components of Dörnyei's L2 motivational self system and some related motivational/attitudinal factors for junior high and high school students learning English as a compulsory school subject. Overall, the results showed that junior high and high school students both enjoyed positive attitudinal and motivational dispositions and the main predictor of students' motivated learning behavior was their attitude towards learning English. In support of the general finding of many studies conducted in various linguistic contexts where foreign language learning is compulsory, students' motivation was found to decline with age. In fact, junior high school students had higher motivational dispositions than high school students except for their attitudes to L2 community. The findings reflect the impacts of age, family, significant others, society at large, and the current socio-educational status of Iran on forming students' visualization of their future L2 self and motivated learning behavior. Since L2 learning experience is very important in shaping learners' attitudes towards language learning (i.e., the most influential factor in motivating students), factors in the immediate environment should be carefully chosen. The education system, authorities, teachers and other stakeholders should make wise decisions because of the long-lasting imprints they have on students' language learning attitudes and motivation. The recent reform in Iran's education system and the newly designed book series (i.e., English for Schools) and the changes in teaching methodology are some positive steps in providing a motivating environment. Further studies may investigate how and to what extent factors in the immediate environment may affect learners' motivational disposition. Moreover, comparing motivational status of students who learn English at schools and private language centers as well as language learners who study at different educational levels can provide a full picture of students' motivational state and their actual effort in learning English.

\section{References}

Aliakbari, M. (2004).The Place of culture in the Iranian ELT textbooks in high school level. Paper presented at the 9th Pan-Pacific Association of Applied Linguistics Conference, Namseoul University, Korea. Retrieved 1 March 2012 from http://www.paaljapan.org/resources /proceedings/PAAL9/pdf/Aliakbari.pdf

Al Moghani, H. M. (2003). Students' perceptions of motivation in English language learning in Libya. Durham theses, Durham University. Retrieved 2 January 2013 from http://etheses.dur.ac.uk/1745/

Al-Shehri, A.S. (2009). Motivation and vision: The relation between the ideal L2 self, imagination and visual style. In Z. Dörnyei\& E. Ushioda.(Eds.), Motivation, language identity and the L2 self (pp.164-171). Bristol, UK: Multilingual Matters.

Arnett, J. J. (2002). The Psychology of globalization.American Psychologist, 57, 774-783.

Azarnoosh, M., (2011). Asibshenasi frayande yadgiri va yaddehi zaban inglisi va shenasai rahkarhaye kaheshe oft tahsili dar mghate rahnamai va motavaset eostan semnan [The pathology of the process of teaching and learning English and the identification of the means to decrease underachievement in junior high and high schools of Semnan province], Unpublished research project, Education Organization of Semnan, Semnan. (In Persian).

Azarnoosh, M., \& Birjandi, P. (2012). Junior high school students' L2 motivational self system: Any gender differences? World Applied Sciences Journal, 20 (4), 577-584, doi: 10.5829/idosi.wasj.2012.20. 04.2732.

Brophy, J. (2009). Connecting with the big picture.Educational Psychologist, 44 (2), 147-157.

Celce-Murcia, M. (2001).Teaching English as a second or foreign language (3rd ed.). Boston: Heinle\&Heinle. 
Chalak, A. \& Kassaian, Z. (2010).Motivation and attitudes of Iranian undergraduate EFL students towards learning English. GEMA Online ${ }^{\mathrm{TM}}$ Journal of Language Studies, 10(2), 37-56.

Clément, R., Dörnyei, Z., \& Noels, K.A., (1994). Motivation, self-confidence, and group cohesion in the foreign language classroom. Language Learning, 44, 417-448.

Cohen, J. (1988). Statistical power analysis for the behavioral sciences. Hillsdale, NJ: Erlbaum.

Csizér, K., \& Dörnyei, Z. (2005).The internal structure of language learning motivation and its relationship with language choice and learning effort.Modern Language Journal, 89(1),19-36.

Csizér, K., \& Kormos, J. (2009). Learning experiences, selves and motivated learning behavior: A comparative analysis of structural models for Hungarian secondary and university learners of English. In Z. Dörnyei\& E. Ushioda.(Eds.), Motivation, language identity and the L2 self(pp.98-119).Clevdon: Multilingual Matters.

Csizér, K., \& Lukács, G. (2010). The comparative analysis of motivation, attitudes and selves: The case of English and German in Hungary. System, 38, 1-13.

Dahmardeh, M. (2009). Communicative Textbooks: English Language Textbooks in Iranian Secondary School. Linguistik online, 40(4), 45-61.

Dastgheib, A. (1996). The role attitudes and motivation in second/foreign language learning. Unpublished $\mathrm{PhD}$ dissertation, Islamic Azad University, Science \& Research Branch, Tehran, Iran.

Dörnyei, Z. (1990). Conceptualizing motivation in foreign-language learning.Language Learning, 40, 45-78.

Dörnyei, Z. (1994). Understanding second language motivation: On with the challenge! Modern Language Journal 79, 505-518.

Dörnyei, Z. (2000). Motivation in action: Toward a process-oriented conceptualization of student motivation. British Journal of Educational Psychology, 70, 519-538.

Dörnyei, Z. (2001). Motivational strategies in the language classroom.Cambridge: Cambridge University Press.

Dörnyei, Z. (2005). The psychology of the language learner: individual differences in second language acquisition. Mahwah, NJ: Lawrence Erlbaum Associates.

Dörnyei, Z. (2007). Research methods in applied linguistics: Quantitative, qualitative and mixed methodologies. Oxford: Oxford University Press.

Dörnyei, Z. (2009). The L2 motivational self system.In Z. Dörnyei\& E. Ushioda.(Eds.), Motivation, language identity and the L2 self (pp.9-42). Bristol, UK: Multilingual Matters.

Dörnyei, Z. (2010). Researching motivation: From integrativeness to the ideal L2 self. In S. Hunston\& D. Oakey. (Eds.), Introducing applied linguistics: Concepts and skills (pp. 74-83).London: Routledge.

Dörnyei, Z., \& Csizér, K. (2002). Some dynamics of language attitudes and motivation: results of a longitudinal nationwide survey. Applied Linguistics, 23, 421-462.

Dörnyei, Z., Csizér, K., \&Németh, N. (2006).Motivation, Language Attitudes and Globalisation: A Hungarian Perspective. Clevedon: Multilingual Matters.

Dörnyei, Z., \& Ottó, I. (1998). Motivation in action: a process model of L2 motivation. Working Papers in Applied Linguistics, 4. Thames Valley University, London.

Dörnyei, Z., \& Ushioda, E. (Eds.) (2009a).Motivation, language identity and the L2 self.Clevedon: Multilingual Matters.

Dörnyei, Z., \& Ushioda, E. (2009b). Motivation, language identities and the L2 self: Future research directions. In Z. Dörnyei,\&E. Ushioda (Eds.), Motivation, Language Identity and the L2 Self (pp.350-356).Clevedon: Multilingual Matters.

Dörnyei, Z., \& Ushioda, E. (2011). Teaching and researching motivation ( $2^{\text {nd }}$ ed.). Harlow: Pearson Education.

Elliott, J.G., Hufton, N.R., Willis, W., \& Illushin, L. (2005). Motivation, engagement and educational performance: International perspectives on the contexts for learning. Hampshire: Palgrave Macmillan.

Ellis, R. (2008). The study of second language acquisition ( $2^{\text {nd }}$ ed.). Oxford: OUP.

Eslami, Z.R., \& Fatahi, A. (2008). Teachers' sense of self-efficacy, English proficiency, and instructional strategies: A study of nonnative EFL teachers in Iran. TESL-EJ, 11(4),1-19.

Gardner, R.C. (1985). Social psychology and second language learning: The role of attitudes and motivation. London: Edward Arnold.

Gardner, R. C. (2001). Integrative motivation and second language acquisition.In Z. Dörnyei \& R. Schmidt (Eds.), Motivation and second language acquisition (pp. 1-19). Technical Report 23, Honolulu: University of Hawai'i, Second Language Teaching and Curriculum Center.

Ghenghesh, P. (2010). The motivation of 12 learners: Does it decrease with age? English Language Teaching, 3(1), 128141 . 
Haddad Narafshan, M., \& Yamini, M. (2011). Policy and English Language Teaching (ELT) in Iran. The Iranian EFL Journal, 7(5), 179-189.

Henry, A. (2009). Gender differences in compulsory school pupils' L2 self-concepts: A longitudinal study. System, 37(2), 177-193.

Higgins, E.T. (1987). Self-discrepancy: A theory relating self and affect. Psychological Review, 94, 319-340.

Kheirabadi,R., \& Alavi Moghaddam, S.B. (2014). New horizons in teaching English in Iran: A transition from readingbased methods to communicative ones by "English for School Series". International Journal of Language Learning and Applied Linguistics World, 5(4), 225-232.

Kiany, G. R., Mahdavy, B., \&Ghafar Samar, R. (2012). Motivational changes of learners in a traditional context of English education: A case study of high school students in Iran. International Journal of Research Studies in Language Learning,2(1), 3-16.

Kim, T. (2009). The sociocultural interface between ideal self and ought-to self: A case study of two Korean students' ESL motivation. In Z. Dörnyei \& E. Ushioda.(Eds.), Motivation, language identity and the L2 self (pp. 274294).Clevdon: Multilingual Matters.

Kim, T.Y. (2010). Reductionism, activity theory, and L2 motivation research: Toward new concepts and definitions. The SNU Journal of Education Research, 19, 1-32. Retrieved on October 26, 2011 from: http://works.bepress.com/taeyoungkim/17

Kormos, J., \& Csizér, K. (2008). Age-related differences in the motivation of learning English as a foreign language: Attitudes, selves, and motivated learning behavior. Language Learning, 58 (2), 327-355.

Lamb, M., (2007). The impact of school on EFL learning motivation: an Indonesian case study. TEOSL Quarterly, 41(4), 757-780.

Lamb, M. (2009). Situating the L2 self: Two Indonesian school learners of English. In Z. Dörnyei\& E. Ushioda (Eds.), Motivation, language identity and the L2 self (pp. 229-247). Clevdon: Multilingual Matters.

MacIntyre, P. D., Baker, S. C., Clément, R., \& Donovan, L. A. (2002). Sex and age effects on willingness to communicate, anxiety, perceived competence, and L2 motivation among junior high school French immersion students. Language Learning, 52(3), 537-564.

MacIntyre, P. D., Clément, R., Dörnyei, Z., \& Noels, K.A. (1998). Conceptualizing willingness to communicate in a L2: A situational model of L2 confidence and affiliation. Modern Language Journal, 82, 545-562.

Markus, H., \&Nurius, P. (1986).Possible selves.American Psychologist, 41, 954-969.

Matsubara, K. (2006). Learning environments and their influences on learner motivation. In K. Bradford-Watts, C. Ikeguchi, \& M. Swanson (Eds.) JALT2005 Conference Proceedings.Tokyo: JALT.

Moiinvaziri, M. (2007). Motivational orientation in English language learning: A study of Iranian undergraduate students. Retrieved on July 10, 2011 from: http://www.usingenglish.com/articles/motivational-orientation- in-englishlanguage-learning.html

Nikolov, M. (1999). 'Why do you learn English?' 'Because the teacher is short.'A study of Hungarian children's foreign language learning motivation.Language Teaching Research, 3, 33-56.

Noels, K.A. (2001).New orientations in language learning motivation: Toward a contextual model of intrinsic, extrinsic, and integrative orientations and motivation. In Z. Dörnyei\& R. Schmidt (Eds.), Motivation and secondlanguage acquisition (pp. 43-68). Honolulu: University of Hawaii, Second Language Teaching \& Curriculum Center.

Noels, K.A. (2003). Learning Spanish as a second language: learners' orientations and perceptions of their teachers' communication style.In Z. Dörnyei\& E. Ushioda.(Eds.), Motivation, language identity and the L2 self (pp. 97-136). Bristol, UK: Multilingual Matters.

Öhlund, A.(2007). Motivation and attitudes in English: A study based on student opinions in the compulsory and the non-compulsory school systems. Retrieved 2 January 2013 from http://dooku.miun.se/engelska/englishC /Cessay/HT07/Final/Ling/\%C3\%85sa_\%C3\%96hlund_CEssay_Final_Version.pdf

Oyserman, D., \& Markus, H. R.(1990).Possible selves in balance.Journal of Social Issues, 46(2), 141-157.

Papi, M. (2010) The L2 motivational self system, L2 anxiety, and motivated behavior: A structural equation modeling approach.System, 38, 467-479. doi:10.1016/j.system.2010.06.011.

Papi, M., \& Abdollahzadeh, E.(2012). L2 teacher motivational practice, student motivation and possible L2 selves: An examination in the Iranian EFL context. Language Learning, 62(2), 571-594. doi: 10.1111/j.1467-9922.2011.00632.x

Papi, M., \& Teimouri, Y. (2012). Dynamics of selves and motivation: A cross-sectional study in the EFL context of Iran. International Journal of Applied Linguistics. 22(3), 287-309. doi: 10.1111/j.1473-4192.2012. 00312.x

Rahimi, M., Riazi, A., \& Saif, S., (2008). An investigation into the factors affecting the use of language learning strategies by Persian EFL learners. RCLA • CJAL, 11(2), 31-60. 
Ryan, S. (2009). Self and identity in L2 motivation in Japan: The ideal L2 self and Japanese learners of English. InZ. Dörnyei, \&E. Ushioda (Eds.), Motivation, Language Identity and the L2 Self(pp. 120-143). Multilingual Matters: Clevedon.

Segalowitz, N., Gatbonton, E., \&Trofimovich, P. (2009). Links between ethnolinguistic affiliation, self-related motivation and second language fluency: Are they mediated by psycholinguistic variables? InZ. Dörnyei, \&E. Ushioda (Eds.), Motivation, Language Identity and the L2 Self(pp. 172-192). Clevedon: Multilingual Matters.

Shedivy, S. L.(2004). Factors that lead some students to continue the study of foreign language past the usual 2 years in high school.System, 32, 103-119.

Shoaib, A., \&Dörnyei, Z. (2005). Affect in life-long learning: Exploring L2 motivation in a dynamic process. In Benson P., Nunan, D. (Eds.), Learners' stories: Difference and diversity in language learning. Cambridge University Press, Cambridge, pp. 22-41.

Taguchi, T., Magid, M., \& Papi, M. (2009). The L2 motivational self system amongst Chinese, Japanese, and Iranian learners of English: A comparative study. In Z. Dörnyei\& E. Ushioda (Eds.), Motivation, language identity and the L2 self (pp. 66-97). Clevedon: Multilingual Matters.

Ushioda, E.(1996). Developing a dynamic concept of motivation.InT. J. Hickey (Ed.), Language, education and society in a changing world (pp. 239-245).Clevedon: Multilingual Matters.

Ushioda, E. (2001). Language learning at university: Exploring the role of motivational thinking. In Z. Dörnyei\& E. Ushioda. (Eds.), Motivation, language identity and the L2 self (pp. 91-124). Bristol, UK: Multilingual Matters.

Vaezi, Z. (2008). Language learning motivation among Iranian undergraduate students. WorldApplied Sciences Journal, 375(1), 54-61.

Waninge, F. (2010).The elusive motivation: The development of motivation in real time. Master's thesis, University of Groningen.

Wigfield, A., \& Wagner, A. L. (2005).Competence, motivation, and identity development during adolescence. In: Elliot, A. J., Dweck, C. S. (Eds.), Handbook of competence and motivation. The Guilford Press, New York, pp.222-240. Williams, M., \& Burden, L. R.(1997).Psychology for language teachers. Cambridge: Cambridge University Press.

Williams, M., Burden, R., \& Lanvers, U. (2002). 'French is the language of love and stuff': Student perceptions of issues related to motivation in learning a foreign language. British Educational Research Journal, 28, 503-528.

Yang, J., \& Kim, T. (2011).The L2Motivational Self System and Perceptual Learning Styles of Chinese, Japanese, Korean, and Swedish Students.English Teaching, 66(1), 141-162.

Yashima, T. (2009). International posture and the ideal L2 self in the Japanese EFL context. In Z. Dörnyei\& E. Ushioda (Eds.), Motivation, language identity and the L2 self (pp. 144- 163). Bristol, UK: Multilingual Matters.

\section{Appendix}

Cronbach Alpha coefficients of the scales

\begin{tabular}{|c|c|c|c|}
\hline Scales & Items & $\begin{array}{c}\text { Junior } \\
\text { High } \\
\text { school }\end{array}$ & $\begin{array}{c}\text { High } \\
\text { school }\end{array}$ \\
\hline Ideal L2 Self & $\begin{array}{l}\text { - I can imagine myself speaking English as if I were a native speaker } \\
\text { of English. } \\
\text { - I can imagine myself speaking English with international friends or } \\
\text { colleagues. } \\
\text { - Whenever I think of my future career, I imagine myself using } \\
\text { English. } \\
\text { - I can imagine myself studying in a university where all my courses } \\
\text { are taught in English. } \\
\text { - I can imagine myself writing English e-mails fluently. } \\
\text { - I can imagine myself living abroad and using English effectively for } \\
\text { communicating with the locals. }\end{array}$ & .80 & .80 \\
\hline Ought-to L2 Self & $\begin{array}{l}\text { - I study English because close friends of mine think it is important. } \\
\text { - If I fail to learn English, I'll be letting other people down. } \\
\text { - I consider learning English important because the people I respect } \\
\text { think that I should do it. } \\
\text { - Studying English is important to me in order to gain the approval of } \\
\text { my peers/teachers/family/boss. } \\
\text { - Learning English is necessary because people surrounding me } \\
\text { expect me to do so. } \\
\text { - Studying English is important to me because other people will } \\
\text { respect me more if I have a knowledge of English }\end{array}$ & .70 & .77 \\
\hline
\end{tabular}




\begin{tabular}{|c|c|c|c|}
\hline $\begin{array}{l}\text { Instrumentality } \\
\text { promotion }\end{array}$ & $\begin{array}{l}\text { - Studying English can be important to me because I think it will } \\
\text { someday be useful in getting a good job and/or making money. } \\
\text { - Studying English is important to me because English proficiency is } \\
\text { necessary for promotion in the future. } \\
\text { - Studying English can be important to me because I think I'll need it } \\
\text { for further studies. } \\
\text { - Studying English is important to me in order to achieve a special } \\
\text { goal (e.g., to get a degree or scholarship). } \\
\text { - I study English in order to keep updated and informed of recent } \\
\text { news of the world. } \\
\text { - Studying English is important to me because I am planning to study } \\
\text { abroad. }\end{array}$ & .71 & .71 \\
\hline $\begin{array}{l}\text { Instrumentality } \\
\text { prevention }\end{array}$ & $\begin{array}{l}\text { - I have to study English because I don't want to get bad marks in it. } \\
\text { - I have to learn English because without passing the English course I } \\
\text { cannot get my degree. } \\
\text { - I have to study English; otherwise, I think I cannot be successful in } \\
\text { my future career. } \\
\text { - Studying English is important to me because, if I don't have } \\
\text { knowledge of English, I'll be considered a weak learner. } \\
\text { - Studying English is necessary for me because I don't want to get a } \\
\text { poor score or a fail mark in English proficiency tests (TOEFL, } \\
\text { IELTS,...). } \\
\text { - I have to learn English because I don't want to fail the English } \\
\text { course. } \\
\text { - Studying English is important to me, because I would feel ashamed } \\
\text { if I got bad grades in English. } \\
\text { - Studying English is important to me because I don't like to be } \\
\text { considered poorly educated person. }\end{array}$ & .71 & .71 \\
\hline Integrativeness & $\begin{array}{l}\text { - How much would you like to become similar to the people who } \\
\text { speak English? } \\
\text { - How important do you think learning English is in order to learn } \\
\text { more about the culture and art of its speakers? } \\
\text { - How much do you like English? }\end{array}$ & .66 & .62 \\
\hline Criterion measures & $\begin{array}{l}\text { - I would like to spend lots of time studying English. } \\
\text { - I am prepared to expend a lot of effort in learning English. } \\
\text { - I would like to concentrate on studying English more than any other } \\
\text { topic. } \\
\text { - If an English course was offered in the future, I would like to take it. } \\
\text { - If my teacher would give the class an optional assignment, I would } \\
\text { certainly volunteer to do it. } \\
\text { - I would like to study English even if I were not required. }\end{array}$ & .81 & .85 \\
\hline Family influence & $\begin{array}{l}\text { - My parents/family believe that I must study English to be an } \\
\text { educated person. } \\
\text { - Studying English is important to me in order to bring honors to my } \\
\text { family. } \\
\text { - Being successful in English is important to me so that I can please } \\
\text { my parents/relatives. } \\
\text { - My family put a lot of pressure on me to study English. } \\
\text { - My parents encourage me to practice my English as much as } \\
\text { possible. } \\
\text { - I have to study English, because, if I don't do it, my parents will be } \\
\text { disappointed with me. }\end{array}$ & .64 & .75 \\
\hline $\begin{array}{l}\text { Attitudes to } \\
\text { learning English }\end{array}$ & $\begin{array}{l}\text { - Do you like the atmosphere of your English classes? } \\
\text { - Do you find learning English really interesting? } \\
\text { - Do you think time passes faster while studying English? } \\
\text { - Do you always look forward to English classes? } \\
\text { - Would you like to have more English lessons at school? } \\
\text { - Do you really enjoy learning English? }\end{array}$ & .82 & .83 \\
\hline Cultural interest & $\begin{array}{l}\text { - Do you like the music of English-speaking countries (e.g., pop } \\
\text { music)? } \\
\text { - Do you like English films? } \\
\text { - Do you like TV programs made in English-speaking countries? } \\
\text { - Do you like English magazines, newspapers, or books? }\end{array}$ & .67 & .74 \\
\hline $\begin{array}{l}\text { Attitudes to L2 } \\
\text { community }\end{array}$ & $\begin{array}{l}\text { - Do you like the people who live in English-speaking countries? } \\
\text { - Do you like meeting people from English-speaking countries? } \\
\text { - Do you like to travel to English-speaking countries? } \\
\text { - Would you like to know more about people from English-speaking } \\
\text { countries? }\end{array}$ & .73 & .76 \\
\hline
\end{tabular}

